\title{
Pelaksanaan Metode Pembelajaran Picture And Picture Oleh Guru Fikih Di Madrasah Ibtidaiyah Al-Rasyid Simpang Tiga Sungai Luar Kecamatan Batang Tuaka
}

\author{
Nurlianti ${ }^{1}$, Martina Napra Tilora ${ }^{2}$ \\ ${ }^{1}$ Pendidikan Guru Madrasah Ibtidaiyah, STAI Auliaurrasyidin, Tembilahan Riau, Indonesia \\ ${ }^{2}$ Pendidikan Guru Madrasah Ibtidaiyah, STAI Auliaurrasyidin, Tembilahan Riau, Indonesia \\ *Corresponding author: nurlianti@gmail.com \\ *Corresponding author: napratiloramartina@gmail.com
}

\begin{abstract}
Abstrak
Penggunaan metode dalam pembelajaran Fikih sangat diperlukan agar siswa dapat mencapai tujuan pembelajaran, oleh sebab itu, guru perlu menggunakan metode yang bervariasi sehingga peserta didik tidak cepat bosan, dan tujuan pembelajaran yang diharapkan dapat dicapai. Salah satu metode yang dapat meningkatkan efektivitas pembelajaran adalah metode pembelajaran Picture and Picture. Penelitian ini bertujuan untuk mengetahui pelaksanaan metode pembelajaran Picture and Picture oleh guru Fikih di Madrasah Ibtidaiyah Al-Rasyid Simpang TIga Sungai Luar Kecamatan Batang Tuaka dan faktor yang mendukung dan menghambatnya..Berdasarkan hasil penelitian dapat disimpulkan bahwa pelaksanaan metode pembelajaran Picture and Picture oleh guru Fikih di Madrasah Ibtidaiyah Al-Rasyid Simpang TIga Sungai Luar Kecamatan Batang Tuaka diperoleh persentase sebesar $67 \%$ yang dikategorikan "Baik" karena berada pada interval 61\%-80\% dengan faktor yang mendukungnya sikap mental guru yang menginginkan kemudahan bagi siswa menerima materi ajar sehingga menggunakan alat bantu berupa gambar contoh, ketersediaan alat peraga atau media pembelajaran yang memadai di madrasah, ketersediaan buku referensi di perpustakaan sehingga memudahkan guru dan siswa mencari materi pelajaran dan faktor penghambatnya adalah guru kadang-kadang kesulitan dalam menghadapi perbedaan dari siswa, guru kadang-kadang kesulitan dalam menentukan gambar yang cocok/sesuai dengan materi ajar, guru kadang-kadang kesulitan mengatur waktu dalam proses pembelajaran.
\end{abstract}

Kata Kunci: Pelaksanaan, Picture and Picture

\section{PENDAHULUAN}

Mengajar bukan tugas yang ringan bagi seorang guru. Dalam mengajar guru berhadapan dengan sekelompok siswa dimana mereka adalah makhluk hidup yang memerlukan bimbingan dan pembinaan untuk menuju kedewasaan. Siswa setelah mengalami proses pendidikan dan pengajaran diharapkan telah menjadi manusia dewasa 
yang sadar tanggung jawab terhadap diri sendiri, berjiwa wiraswasta, berpribadi dan bermoral. ${ }^{1}$

Agar Proses pembelajaran dapat berjalan dengan baik maka diperlukan suatu perencanaan yang matang sebelum proses pembelajaran dilaksanakan. Rencana ini tertuang dalam Rencana Pelaksanaan Pembelajaran. Menurut Masnur Muslich, rencana yang dimaksud yaitu rancangan pembelajaran mata pelajaran per unit/materi yang akan diterapkan oleh guru dalam pembelajaran di kelas. ${ }^{2}$

Pada hakekatnya pembelajaran merupakan sebuah proses atau kegiatan yang memiliki tujuan atau target, adakalanya kegiatan pembelajaran berhasil, tetapi tidak jarang mengalami kegagalan dalam mengatarkan siswa mencapai tujuan atau target yang ditetapkan. Parameter (ukuran) keberhasilan pencapaian tujuan atau target pembelajaran ditetapkan ke dalam Standar Kompetensi Lulusan (SKL). Siswa dinyatakan berhasil mencapai tujuan pembelajaran bilamana mencapai kriteria ketuntasan minimal (KKM), yaitu nilai minimal yang harus dicapai siswa agar dapat dinyatakan lulus. Salah satu factor yang dapat menunjang keberhasilan dalam mencapai tujuan pembelajaran adalah metode mengajar yang digunakan oleh guru.

Metode mengajar merupakan sebuah rencana menyeluruh untuk sebuah penyajian materi yang tersusun rapi, baik dilihat dari susunan dan urutan materi sesuai dengan ruang lingkup setiap ketentuan yang merupakan asumsi dasar tentang materi itu sendiri. Menurut Syaiful Bahri Djamarah dan Aswan Zain, salah satu kegiatan yang harus guru lakukan adalah melakukan pemilihan dan penentuan metode yang bagaimana yang akan dipilih untuk mencapai tujuan pengajaran. ${ }^{3}$

Penggunaan metode yang sesuai diperlukan pula pada pembelajaran Fikih. Namun pada kenyataannya dijumpai seorang guru hanya menggunakan metode ceramah dalam menyampaikan materi Fikih sehingga aktivitas belajar siswa hanya sebatas mendengar. Dampak negatifnya adalah materi tidak tersimpan lama dalam ingatan siswa sehingga pada saat diberikan evaluasi berupa ulangan harian, hasil belajar siswa tidak mencapai kriteria ketuntasan minimal (KKM). Oleh sebab itu untuk memperbaiki pembelajaran Fikih di madrasah ibtidaiyah diperlukan pembenahan metode pembelajaran yang tepat.

Hal yang bisa dilakukan guru adalah dengan melakukan pemilihan dan penerapan metode harus disesuaikan dengan keadaan siswa dan lingkungan sekitar, serta materi yang akan disampaikan. Oleh sebab itu guru perlu menggunakan metode yang bervariasi sehingga peserta didik tidak cepat bosan, dan tujuan pembelajaran yang diharapkan dapat dicapai. Salah satu metode yang dapat meningkatkan aktivitas belajar siswa adalah metode pembelajaran Picture and Picture.

Junaedi $\mathrm{dkk}$, mengatakan bahwa metode pembelajaran picture and picture merupakan suatu metode belajar yang menggunakan gambar dan dipasangkan/diurutkan

${ }^{1}$ Daryanto, Belajar dan Mengajar, (Bandung: Yrama Widya, 2010), hlm. 164-165.

${ }^{2}$ Masnur Muslich, KTSP Kurikulum Tingkat Satuan Pendidikan, (Jakarta:PT Bumi Aksara, 2008), hlm. 45.

${ }^{3}$ Syaiful Bahri Djamarah dan Aswan Zain, Strategi Belajar Mengajar, (Jakarta: Rineka Cipta, 2005), hlm. 77. 
menjadi urutan logis. ${ }^{4}$ Selain itu, metode picture and picture ini juga melibatkan keaktifan dan kerjasama siswa dalam pembelajaran yaitu siswa melakukan diskusi kelompok dan menyampaikan hasil diskusinya sehingga proses pembelajaran yang dilakukan akan lebih berkesan dan bermakna.

Penerapan metode pembelajaran picture and picture akan memungkinkan siswa lebih aktif di dalam kelas karena siswa diberikan sajian gambar dari materi yang dibahas selanjutnya mereka disuruh berdiskusi bersama kelompoknya dan menguraikan maksud gambar yang ada di hadapan mereka. Hal ini dikarenakan metode picture and picture memberikan keuntungan yang banyak bagi siswa.

\section{METODE PENELITIAN}

Penelitian ini menggunakan metode kualitatif, untuk mengumpulkan data yang sesuai dengan kepentingan penelitian ini penulis menggunakan teknik pengumpulan data observasi dan wawancara. Observasi dalam metodologi penelitian adalah teknik pengumpulan data melalui pengamatan untuk memahami, mencari jawaban dan bukti terhadap gejala, peristiwa, kejadian atau realitas yang diteliti, baik berupa perilaku, keadaan, benda, maupun simbol-simbol tertentu. ${ }^{5}$ Wawancara adalah teknik pengumpulan data dengan cara mengajukan pertanyaan langsung secara lisan oleh pewawancara (interviewer) kepada individu yang diwawancarai (interviewe) yang disebut informan. ${ }^{6}$

Tekhnik analisis data yang digunakan oleh peneliti adalah Triangulasi dapat dilakukan dengan jalan antara lain; 1) membandingkan data hasil pengamatan dengan data hasil wawancara, 2) membandingkan apa yang dikatakan orang di depan umum dengan apa yang dikatakannya secara pribadi, 3) membandingkan apa yang dikatakan orang-orang tentang situasi penelitian dengan apa yang dikatakan sepanjang waktu, 4) membandingkan keadaan dan perspektif seorang dengan berbagai pendapat dan pandangan orang sebagai rakyat biasa, orang yang berpendidikan menengah atau tinggi, orang berada, orang pemerintah, 5) membandingkan hasil wawancara dengan isi suatu dokumen yang berkaitan. Data yang diperoleh melalui observasi dan wawancara dapat dipaparkan dengan teknik deskriptif, yaitu teknik menggambarkan fenomena yang diperoleh dengan apa adanya, kemudian diklasifikasikan dan digambarkan dengan kalimat.

${ }^{4}$ Junaedi, dkk., Strategi Pembelajaran, (Surabaya: LAPIS PGMI, 2008), hlm. 11.13-11.14.

${ }^{5}$ Hidayat Syah, op.cit., hlm. 130.

${ }^{6}$ Ibid., hlm. 122. 


\section{HASIL DAN PEMBAHASAN}

Berdasarkan hasil penelitian diketahui bahwa pelaksanaan metode pembelajaran picture and picture oleh guru Fikih di Madrasah Ibtidaiyah Al-Rasyid Simpang Tiga Sungai Luar Kecamatan Batang Tuaka diperoleh persentase sebesar 67\% yang dikategorikan "Baik" karena berada pada interval 61\%-80\%. Selanjutnya wawancara yang telah penulis lakukan, dapat diambil kesimpulan faktor-faktor pendukung dan penghambat dari pelaksanaan metode pembelajaran picture and picture oleh guru Fikih di Madrasah Ibtidaiyah Al-Rasyid Simpang Tiga Sungai Luar Kecamatan Batang Tuaka, antara lain:

Berdasarkan data yang diperoleh dari teknik pengumpulan data observasi, wawancara dan dokumentasi serta melalui tahapan analisis, maka di peroleh hasil:

1. Pelaksanaan metode pembelajaran picture and picture oleh guru Fikih di Madrasah Ibtidaiyah Al-Rasyid Simpang Tiga Sungai Luar Kecamatan Batang Tuaka diperoleh persentase sebesar $67 \%$ yang dikategorikan "Baik" karena berada pada interval $61 \%-80 \%$.

2. Faktor-faktor pendukung dan penghambat dari pelaksanaan metode pembelajaran picture and picture oleh guru Fikih di Madrasah Ibtidaiyah AlRasyid Simpang Tiga Sungai Luar Kecamatan Batang Tuaka, antara lain

a. Faktor pendukung

1) Sikap mental guru yang menginginkan kemudahan bagi siswa menerima materi ajar sehingga menggunakan alat bantu berupa gambar contoh.

2) Ketersediaan alat peraga atau media pembelajaran yang memadai di madrasah.

3) Ketersediaan buku referensi di perpustakaan sehingga memudahkan guru dan siswa mencari materi pelajaran.

b. Faktor penghambat

1) Guru kadang-kadang kesulitan dalam menghadapi perbedaan dari siswa.

2) Guru kadang-kadang kesulitan dalam menentukan gambar yang cocok/sesuai dengan materi ajar.

3) Guru kadang-kadang kesulitan mengatur waktu dalam proses pembelajaran

Metode pembelajaran Picture and picture merupakan salah satu bagian dari pembelajaran kooperatif. Oleh karena itu, sebelum membahas tentang pengertian metode pembelajaran Picture and picture perlu dibahas terlebih dahulu pengertian pembelajaran kooperatif atau cooperative learning.

Pembelajaran kooperatif (cooperatif learning) menurut Junaedi, dkk., memberikan makna sebagai berikut: "Pembelajaran kooperatif (cooperatif learning) memiliki arti belajar bersama yang melibatkan antara 4-5 siswa yang bekerja bersama menuju kelompok kerja dimana setiap anggota bertanggungjawab secara individu sebagai bagian dari hasil yang tak akan bisa dicapai tanpa adanya kerjasama antar kelompok".

${ }^{7}$ Junaedi, dkk, Op. Cit.,, hlm. 8.9. 
Menurut Rusman, Cooperative Learning adalah bentuk pembelajaran dengan cara siswa belajar dan bekerja dalam kelompok-kelompok kecil secara kolaboratif yang anggotanya terdiri dari empat sampai enam orang dengan struktur kelompok yang bersifat heterogen. ${ }^{8}$ Menurut Robert E. Slavin, apabila diatur dengan baik, siswa-siswa dalam kelompok kooperatif akan belajar satu sama lain untuk memastikan bahwa tiap orang dalam kelompok telah menguasai konsep-konsep yang telah dipikirkan. ${ }^{9}$

Menurut Trianto, di dalam kelas kooperatif siswa belajar bersama dalam kelompokkelompok kecil yang terdiri dari 4-6 orang siswa yang sederajat tetapi heterogen, kemampuan, jenis kelamin, suku/ras, dan satu sama lain saling membantu. Tujuan dibentuknya kelompok tersebut adalah untuk memberikan kesempatan kepada semua siswa untuk dapat terlibat secara aktif dalam proses berpikir dan kegiatan belajar. Selama bekerja dalam kelompok, tugas anggota kelompok adalah mencapai ketuntasan materi yang disajikan oleh guru dan saling membantu teman sekelompoknya untuk mencapai ketutasan belajar. ${ }^{10}$

Berdasarkan berbagai pendapat di atas, dapat disimpulkan bahwa pembelajaran kooperatif adalah salah satu bentuk pembelajaran yang berdasarkan faham konstruktivis. Pembelajaran kooperatif merupakan strategi belajar dengan sejumlah siswa sebagai anggota kelompok kecil yang tingkat kemampuannya berbeda. Dalam menyelesaikan tugas kelompoknya, setiap siswa anggota kelompok harus saling bekerja sama dan saling membantu untuk memahami materi pelajaran. Dalam pembelajaran kooperatif, belajar dikatakan belum selesai jika salah satu teman dalam kelompok belum menguasai bahan pelajaran.

Metode pembelajaran Picture and picture merupakan salah satu metode yang dapat digunakan dalam pembelajaran kooperatif (cooperative learning), yang dapat memberi petunjuk dan kesempatan kepada siswa dalam menggunakan otaknya untuk berfikir dan memperoleh pengertian tentang konsep.

Menurut Junaedi dkk, menyatakan bahwa metode picture and picture adalah "suatu metode belajar yang menggunakan gambar dan dipasangkan/diurutkan menjadi urutan logis". ${ }^{11}$ Sedangkan menurut Hamdani, Picture and Picture adalah suatu metode belajar yang menggunakan gambar yang dipasangkan atau diurutkan menjadi urutan logis. ${ }^{12}$

Berdasarkan pendapat tersebut dapat disimpul-kan bahwa metode pembelajaran picture and picture adalah suatu metode pembelajaran dengan menggunakan gambar yang disajikan kepada siswa berkenaan materi yang sedang dibahas oleh guru dalam proses pembelajaran..

\footnotetext{
${ }^{8}$ Rusman, Manajemen Kurikulum, (Jakarta: RajaGrafindo Persada, 2011), hlm. 197.

${ }^{9}$ Robert E. Slavin, Cooperatifve Learning, Teori, Riset dan Praktik, (Bandung: Nusa Media, 2005), hlm. 4.

${ }^{10}$ Trianto, Mendesaian Model Pembelajaran Inovatif Progresif, (Jakarta: Kencana, 2010), hlm. 56

${ }^{11}$ Junaedi, dkk, op.cit., hlm. 11.13-11.14.

${ }^{12}$ Hamdani, Strategi Belajar Mengajar, (Bandung: Pustaka Setia, 2011), hlm. 89.
} 
Dalam pandangan Junaedi, dkk., metode ini memiliki kelebihan diantaranya:

1. Guru lebih mengetahui kemampuan masing-masing peserta didik.

2. Melatih berpikir logis dan sistematis. ${ }^{13}$

Dalam pembelajaran yang menggunakan metode Picture and Picture, guru menggunakan gambar sebagai media pembelajaran. Menurut Arief S. Sadiman,dkk., beberapa kelebihan media gambar adalah:

1) Gambar lebih realistis menunjukkan pokok masalah dibandingkan dengan media verbal semata.

2) Gambar dapat mengatasi batasan ruang dan waktu. Karena tidak semua benda, objek atau peristiwa dapat dibawa ke kelas.

3) Media visual dapat mengatasi keterbatasan pengamatan kita

4) Gambar harganya murah dan gampang didapat serta digunakan, tanpa memerlukan peralatan khusus. ${ }^{14}$

Sedangkan kelemahan dari metode ini adalah:

a. Memakan waktu yang lama.

b. Banyak peserta didik yang pasif ${ }^{15}$

Menurut Junaedi, dkk., memberikan rincian langkah-langkah pelaksanaan metode pembelajaran picture and picture diantaranya:

a. Guru menyampaikan kompetensi yang ingin dicapai.

b. Menyajikan materi sebagai pengantar.

c. Guru menunjukkan/memperlihatkan gambar-gambar yang berkaitan dengan materi.

d. Guru menunjuk/memanggil siswa secara bergantian memasang/mengurutkan gambar-gambar menjadi urutan yang logis.

e. Guru menanyakan alasan/dasar pemikiran urutan gambar tersebut.

f. Dari alasan/urutan gambar tersebut guru memulai menanamkan konsep/materi sesuai dengan kompetensi yang ingin dicapai.

g. Kesimpulan/rangkuman. ${ }^{16}$

Menurut Agus Suprijono langkah-langkah metode pembelajaran picture and picture diantaranya:

a. guru menyampaikan kompetensi yang ingin dicapai.

b. Menyajikan materi sebagai pengantar.

c. Guru menunjukkan/memperlihatkan gambar-gambar kegiatan berkaitan dengan materi.

d. Guru menunjuk/memanggil siswa secara bergantian memasang/menggurutkan gambar-gambar menjadi urutan yang logis.

e. Guru menanyakan alasan/dasar pemikiran urutan gambar tersebut.

\footnotetext{
${ }^{13}$ Junaedi, dkk., op.cit., hlm. 11.14.

${ }^{14}$ Arief S. Sadiman, dkk., Media Pendidikan, (Jakarta: RajaGrafindo Persada, 2008), hlm. 30-31.

${ }^{15}$ Junaedi, dkk., op.cit., hlm. 11.14.

${ }^{16}$ Ibid., hlm. 11.14.
} 
f. Dari alasan/urutan gambar tersebut guru memulai menanamkan konsep/materi sesuai dengan kompetensi yang ingin dicapai.

g. Kesimpulan/rangkuman. ${ }^{17}$

Menurut Yatim Riyanto langkah dalam pelaksanaan metode pembelajaran picture and picture adalah:

a. Guru menyampaikan kompetensi yang ingin dicapai dalam proses pembelajaran.

b. Guru menyajikan materi sebagai penngatar.

c. Guru menunjukkan/memperlihatkan gambar-gambar kegiatan berkaitan dengan materi.

d. Guru menunjuk/memanggil siswa secara bergantian memasang/menggurutkan gambar-gambar menjadi urutan yang logis.

e. Guru menanyakan alasan/dasar pemikiran urutan gambar tersebut.

f. Berdasarkan alasan urutan gambar tersebut guru memulai menanamkan konsep/materi sesuai dengan kompetensi yang ingin dicapai.

g. Guru menyimpulkan dan rangkuman. ${ }^{18}$

Menurut Hamdani, langkah-langkah pelaksanaan metode pembelajaran picture and picture adalah:

a. Guru menyampaikan kompetensi yang ingin dicapai.

b. Guru menyajikan materi sebagai pengantar.

c. Guru menunjukkan atau memperlihatkan gambar-gambar yang berkaitan dengan materi.

d. Guru menunjuk atau memanggil siswa secara bergantian untuk memasang atau mengurutkan gambar-gambar menjadi urutan yang logis.

e. Guru menanyakan alasan atau dasar pemikiran urutan gambar tersebut.

f. Dari alasan atau urutan gambar tersebut, guru menanamkan konsep atau materi sesuai dengan kompetensi yang ingin dicapai.

g. Kesimpulan. ${ }^{19}$

Berdasarkan pendapat-pendapat di atas dapat diketahui langkah-langkah pelaksanaan metode pembelajaran picture and picture diantaranya:

a. Guru menyampaikan kompetensi yang ingin dicapai.

b. Guru menyajikan materi sebagai pengantar.

c. Guru menunjukkan/memperlihatkan gambar-gambar yang berkaitan dengan materi.

d. Guru menunjuk/memanggil siswa secara bergantian memasang/mengurutkan gambar-gambar menjadi urutan yang logis.

e. Guru menanyakan alasan/dasar pemikiran urutan gambar tersebut

f. Guru menanamkan konsep/materi sesuai dengan kompetensi yang ingin dicapai berdasarkan alasan dari siswa.

\footnotetext{
${ }^{17}$ Agus Suprijono, Cooperative Learning: Teori dan Aplikasi PAIKEM, (Yogyakarta: Pustaka Pelajar, 2012), hlm. 125-126.

${ }^{18}$ Yatim Riyanto, Paradigma Baru Pembelajaran, (Jakarta: Kencana, 2009), hlm. 282.

${ }^{19}$ Hamdani, Loc. Cit.
} 
g. Guru memberikan kesimpulan/rangkuman materi ajar.

Beberapa faktor pendukung dan penghambat dalam pelaksanaan metode pembelajaran picture and picture adalah sebagai berikut:

1. Faktor-Faktor Pendukung

Faktor-faktor pendukung pelaksanaan metode pembelajaran Picture and Picture diantaranya dapat dilihat dari segi guru, sumber/sarana/fasilitas, dan siswa. Sebagaimana menurut pendapat Zuhairini yang dikutip oleh Muhammad Hidayat bahwa faktor-faktor pendukung pelaksanaan suatu metode pembelajaran adalah:

a. Sikap mental guru

Para guru hendaknya menyadari tentang perlunya pembaharuan metode belajar mengajar. Untuk itu para konsertatif diharapkan mengikuti tentang pembaharuan tersebut. Sehingga mempunyai kesiapan mental untuk melaksanakan pendekatan belajar aktif (active learning strategy) sebagai hasil dari adanya pembaharuan pendidikan.

b. Kemampuan guru

Para guru hendaknya mempunyai beberapa kemampuan yang dapat menunjang keberhasilan dalam melaksanakan kegiatan belajar mengajar. Seorang guru dituntut untuk mampu menguasai isi pokok pelajaran yang akan disampaikan dalam mengajar. Guru harus mampu mengatur siswa dengan baik, mengembangkan metode mengajar yang diterapkan, mengadakan evaluasi dan membimbing siswanya dengan baik.

c. Penyediaan alat peraga/media

Dalam kegiatan belajar mengajar maka alat atau media sangat diperlukan agar dapat menunjang tercapainya tujuan pendidikan. Alat atau media ini harus diupayakan selengkap mungkin agar segala aktivitas mengajar dapat dibantu dengan media tersebut. Sehingga guru tidak terlalu banyak mengeluarkan tenaga dalam penyampaian materi atau bahan pelajaran yang akan disampaikan

d. Kelengkapan kepustakaan

Kepustakaan sebagai kelengkapan dalam menunjang keberhasilan pengajaran, hendaknya diisi dengan berbagai buku yang relevan sebagai upaya untuk pengayaan terhadap pengetahuan dan pengalaman siswa. Semakin siswa banyak membaca buku akan semakin pula banyak pengetahuan yang dimiliki sehingga wawasan siswa terhadap materi pelajaran akan semakin bertambah, dan pada akhirnya tujuan pengajaran akan mudah tercapai secara efektif dan efisien. ${ }^{20}$

${ }^{20}$ Muhammad Hidayat, Penerapan Strategi Pembelajaran Ekspositori dalam Pembelajaran Bahasa Indonesia, Jurnal Pendidikan Nomor 23 Tahun 2010 Univversitas Negeri Semarang, hlm. $2-3$. 
2. Faktor-Faktor Penghambat

Sedangkan faktor-faktor penghambat pelaksanaan suatu metode pembelajaran dapat disebutkan sebagaimana berikut:

a. Kesulitan dalam menghadapi perbedaan individu siswa.

Perbedaan individu murid meliputi: intelegensi, watak, dan latar belakang kehidupannya. Dalam satu kelas, terdapat anak yang pandai, sedang, dan anak yang kurang pandai. Ada pula anak yang nakal, pendiam, pemarah, dan lain sebagainya. Dalam mengatasi hal ini guru sebaiknya tidak terlalu terikat kepada perbedaan individu siswa, tetapi guru harus melihat siswa dalam kesamaannya secara klasikal, walaupun kedua individu anak pun harus mendapat perhatian.

b. Kesulitan dalam menentukan materi yang cocok dengan siswa.

Materi yang diberikan kepada siswa haruslah disesuaikan dengan kondisi kejiwaan dan jenjang pendidikan mereka, misalkan untuk materi Pendidikan Agama Islam yang diberikan pada siswa di SD janganlah terlalu tinggi, tetapi cukup dengan yang praktis, sehingga mereka dapat langsung menerapkannya dalam kehidupan sehari-hari.

c. Kesulitan dalam memilih metode yang sesuai dengan materi pelajaran

Metode mengajar haruslah disesuaikan dengan materi pelajaran dan juga dengan tingkat kejiwaan siswa, sehingga dalam proses belajar mengajar hendaknya digunakan berbagai macam metode agar murid tidak cepat bosan dalam belajar.

d. Kesulitan dalam memperoleh sumber dan alat-alat pembelajaran.

Alat-alat dan sumber yang digunakan dalam pembelajaran haruslah disesuaikan dengan materi pelajaran, dan seorang guru haruslah pintar-pintar memilih alat-alat dan sumber belajar yang sesuai dengan materi yang akan diajarkan.

e. Kesulitan dalam mengadakan evaluasi dan pengaturan waktu.

Kadang-kadang kelebihan waktu atau kekurangan waktu dapat menyebabkan kegagalan dalam melaksanakan rencana-rencana yang telah ditentukan sebelumnya. Hal ini dapat teratasi apabila seorang guru telah berpengalaman dalam mengajar. ${ }^{21}$

Berdasarkan pendapat di atas dapat disimpulkan faktor-faktor pendukung dan penghambat dalam pelaksanaan metode pembelajaran Picture and Picture adalah:

1. Faktor pendukung

a. Sikap mental guru

b. Kemampuan guru

c. Penyediaan alat peraga/media

d. Kelengkapan kepustakaan

2. Faktor penghambat

a. Kesulitan dalam menghadapi perbedaan individu siswa

${ }^{21}$ Ibid., hlm. 3-4. 
b. Kesulitan dalam menentukan materi yang cocok dengan siswa.

c. Kesulitan dalam memilih strategi yang sesuai dengan materi pelajaran.

d. Kesulitan dalam memperoleh sumber dan alat-alat pembelajaran.

e. Kesulitan dalam mengadakan evaluasi dan pengaturan waktu

\section{Pembelajaran Fiqh}

Mata pelajaran Fikih di Madrasah Ibtidaiyah merupakan salah satu mata pelajaran PAI yang mempelajari tentang fikih ibadah, terutama menyangkut pengenalan dan pemahaman tentang cara-cara pelaksanaan rukun Islam dan pembiasaannya dalam kehidupan sehari-hari, serta fikih muamalah yang menyangkut pengenalan dan pemahaman sederhana mengenai ketentuan tentang makanan dan minuman yang halal dan haram, khitan, kurban, serta tata cara pelaksanaan jual beli dan pinjam meminjam. Secara substansial mata pelajaran Fikih memiliki kontribusi dalam memberikan motivasi kepada peserta didik untuk mempraktikkan dan menerapkan hukum Islam dalam kehidupan sehari-hari sebagai perwujudan keserasian, keselarasan, dan keseimbangan hubungan manusia dengan Allah SWT, dengan diri manusia itu sendiri, sesama manusia, makhluk lainnya ataupun lingkungannya. ${ }^{22}$

Mata pelajaran Fikih di Madrasah Ibtidaiyah bertujuan untuk membekali peserta didik agar dapat:

a. Mengetahui dan memahami cara-cara pelaksanaan hukum Islam baik yang menyangkut aspek ibadah maupun muamalah untuk dijadikan pedoman hidup dalam kehidupan pribadi dan sosial.

b. Melaksanakan dan mengamalkan ketentuan hukum Islam dengan benar dan baik, sebagai perwujudan dari ketaatan dalam menjalankan ajaran agama Islam baik dalam hubungan manusia dengan Allah SWT, dengan diri manusia itu sendiri, sesama manusia, dan makhluk lainnya maupun hubungan dengan lingkungannya. ${ }^{23}$

Ruang lingkup mata pelajaran Fikih di Madrasah Ibtidaiyah meliputi:

a. Fikih ibadah, yang menyangkut: pengenalan dan pemahaman tentang cara pelaksanaan rukun Islam yang benar dan baik, seperti: tata cara taharah, salat, puasa, zakat, dan ibadah haji.

b. Fikih muamalah, yang menyangkut: pengenalan dan pemahaman mengenai ketentuan tentang makanan dan minuman yang halal dan haram, khitan, kurban, serta tata cara pelaksanaan jual beli dan pinjam meminjam. ${ }^{24}$

\footnotetext{
${ }^{22}$ Lampiran Peraturan Menteri Agama Republik Indonesia Nomor 2 Tahun 2008 tentang Standar Kompetensi Lulusan dan Standar Isi Mata Pelajaran Pendidikan Agama Islam dan Bahasa Arab di Madrasah, hlm. 19.

${ }^{23}$ Ibid.

${ }^{24}$ Ibid., hlm. 21.
} 


\section{KESIMPULAN DAN SARAN}

Berdasarkan penelitian yang telah penulis lakukan, dapat disimpulkan sebagai berikut:

1. Pelaksanaan metode pembelajaran picture and picture oleh guru Fikih di Madrasah Ibtidaiyah Al-Rasyid Simpang Tiga Sungai Luar Kecamatan Batang Tuaka diperoleh persentase sebesar $\mathbf{6 7 \%}$ yang dikategorikan "Baik" karena berada pada interval 61\%-80\%.

2. Faktor-faktor pendukung dan penghambat dari pelaksanaan metode pembelajaran picture and picture oleh guru Fikih di Madrasah Ibtidaiyah Al-Rasyid Simpang Tiga Sungai Luar Kecamatan Batang Tuaka, antara lain:

a. Faktor pendukung

1) Sikap mental guru yang menginginkan kemudahan bagi siswa menerima materi ajar sehingga menggunakan alat bantu berupa gambar contoh.

2) Ketersediaan alat peraga atau media pembelajaran yang memadai di madrasah.

3) Ketersediaan buku referensi di perpustakaan sehingga memudahkan guru dan siswa mencari materi pelajaran.

b. Faktor penghambat

1) Guru kadang-kadang kesulitan dalam menghadapi perbedaan dari siswa.

2) Guru kadang-kadang kesulitan dalam menentukan gambar yang cocok/sesuai dengan materi ajar.

3) Guru kadang-kadang kesulitan mengatur waktu dalam proses pembelajaran.

Berdasarkan kesimpulan di atas, saran yang dapat penulis sampaikan, di antaranya:

a. Bagi kepala madrasah

Pihak sekolah sebaiknya memberikan perhatian berupa sosialisasi tentang metode yang lebih inovatif untuk diterapkan dalam pembelajaran Fikih maupun pada mata pelajaran lain.

b. Bagi Guru

Agar terus meningkatkan kemampuannya di bidang pendidikan seperti membuat penelitian tindakan kelas, membuat LKS dan lain-lain agar pembelajaran lebih berkembang ke arah perbaikan mutu proses dan hasil belajar.

\section{DAFTAR PUSTAKA}

Agus Suprijono. 2012. Cooperative Learning: Teori dan Aplikasi PAIKEM. Yogyakarta: Pustaka Pelajar.

Arief S. Sadiman. dkk. 2008. Media Pendidikan. Jakarta: RajaGrafindo Persada.

Daryanto. 2007. Kamus Bahasa Indonesia Lengkap. Surabaya: Apollo Lestari.

Hamdani. 2011. Strategi Belajar Mengajar. Bandung: Pustaka Setia. 
Hidayat Syah. 2010. Pengantar Umum Metodologi Penelitian Pendidikan Pendekatan Verifikatif. Pekanbaru: Suska Press.

Junaedi. dkk. 2008. Strategi Pembelajaran. Surabaya: LAPIS PGMI.

Lexy J. Meolong. 2002. Metode Penelitian Kualitatif. Bandung: Remaja Rosdakarya.

Masnur Muslich. 2008. KTSP Kurikulum Tingkat Satuan Pendidikan. Jakarta:PT Bumi Aksara.

Moh. Sholeh Hamid. 2014. Metode Edutainment. Jogjakarta: DIVA Press.

Muhammad Hidayat. Penerapan Strategi Pembelajaran Ekspositori dalam Pembelajaran Bahasa Indonesia. Jurnal Pendidikan Nomor 23 Tahun 2010 Universitas Negeri Semarang.

Musfiqon. 2012. Panduan Lengkap Metodologi Penlitian Pendidikan. Jakarta: PT Prestasi Pustakaraya.

Robert E. Slavin. 2005. Cooperatifve Learning. Teori. Riset dan Praktik. Bandung: Nusa Media.

Rusman. 2011. Manajemen Kurikulum. Jakarta: RajaGrafindo Persada.

Syaiful Bahri Djamarah dan Aswan Zain. 2005. Strategi Belajar Mengajar. Jakarta: Rineka Cipta.

Trianto. 2010. Mendesaian Model Pembelajaran Inovatif Progresif. Jakarta: Kencana.

Yatim Riyanto. 2009. Paradigma Baru Pembelajaran. Jakarta: Kencana. 